\title{
STUDY OF THE HISTOLOGICAL AND ANATOMICAL CHARACTERISTICS OF THE HUMAN ORAL MUCOSA. \\ A STEP TOWARDS THE DEVELOPEMENT OF TAILORED-ARTIFICIAL ORAL MUCOSA
}

\author{
ESTUDIO DE LAS CARACTERÍSTICAS HISTOLÓGICAS Y \\ ANATÓMICAS DE LA MUCOSA ORAL HUMANA. UN PASO \\ HACIA LA FABRICACIÓN DE MUCOSA ORAL ARTIFICIAL \\ HECHA A MEDIDA
}

\begin{abstract}
Ibáñez Cortés, Miguel ${ }^{1,2}$; Garzón, Ingrid ${ }^{1}$
1 Tissue Engineering Group, Department of Histology, Faculty of Medicine, University of Granada, Spain. 2 Postgraduate Master Program in Tissue Engineering and Advanced Therapies, University of Granada, Spain.
\end{abstract}

Recibido: 04/08/2020 | Revisado: 05/09/2020 | Aceptado: 23/10/2020

DOI: 10.15568/am.2021.813.rev01

Actual Med. 2021; 106(813): 177-187

\section{Revisión}

\begin{abstract}
Several pathologies may affect the histological structure and physiology of the human oral mucosa, being necessary to use oral mucosa grafts. In this context, the scarce number of donors has increased the need to develop artificial substitutes of human oral mucosa, most of them, without attending to the histological differences found in the different anatomical areas of the oral cavity. The objective of the present bibliographic review is to carry out a histological description and a morphological classification of the human oral mucosa and to determine the translational potentiality of the new artificial models of oral mucosa.
\end{abstract}

\section{RESUMEN}

Diversas patologías afectan sustancialmente la estructura histológica y la fisiología de la mucosa oral humana haciendo necesario el uso de trasplantes de mucosa oral. En este contexto, el escaso número de donantes ha incrementado la necesidad de producir sustitutos artificiales de mucosa oral humana, la mayoría de ellos sin atender a las diferencias histológicas encontradas en las diferentes áreas anatómicas de la cavidad oral. El objetivo de la presente revisión bibliográfica es realizar una descripción histológica y una clasificación morfológica de la mucosa oral humana y determinar la potencialidad traslacional de los nuevos modelos artificiales de mucosa oral.
Keywords: Oral Mucosa; Histology: Anatomy; Tissue Engineering.

Palabras clave: Mucosa oral; Histología; Anatomía; Ingeniería Tisular.

\section{INTRODUCTION}

Oral cavity is part of the digestive system delimited by the lips in the anterior area, by the oropharynx in the posterior area, by the hard and soft palates in the superior area and by the tongue and mouth's floor in the inferior area. All of them are surrounded by oral mucosa, lining with the cheeks, teeths and gingiva (1). Histologically, oral mucosa is composed by superficial epithelium and undelying connective tissue and both, epithelium and connective tissues are orchestated by a basement membrane forming a mucosa with underlying less prominent submucosa $(2,3)$. According to this, normal anatomical, histological and physiologycal conditions of the human oral mucosa could be affected by oral pathologies that may vary from infectious (ie, VIH, sifilis), traumatic (ie, traumatic ulcers, Linea Alba), congenital (ie, heterotopia, Bohn's nodules) and oncological (ie, melanome, fibrosarcoma) diseases. In this context, current clinical treatments are mainly focused on the use of oral mucosa grafts (4-7). 
However, the scarce number of oral mucosa donors and the associated drawbacks to the surgical technique, dramatically increase the need of artificial oral mucosa susbtitutes developed by tissue engineering. In this mileu, several oral mucosa models have been produced by tissue engineered varying from models formed by one or more keratinocytes layers mimicking epithelial tissue until full-thickness models consisting of keratinocytes layers and a connective tissue formed by fibroblasts making use of different commertial (ie, Matriderm ${ }^{\circledast}$ ) or non-commertial (ie, fibrin-agarose) scaffolds $(4,8,9)$.

Most of the patients can suffer lesions in the different areas of the oral cavity as gingiva, hard and soft palates, mouth's floor, lips, cheeks, ventral and dorsal tongue, taste papillae or lingual tonsil. Each anatomical area have been associated to specific histological characteristics, as number of epithelial layers, cytokeratin expression profile of epithelial keratinocytes and type of connective tissue which can be lax, semidense or dense $(5,10)$. In this regard, the generation of artificial substitutes includes standarized oral mucosa with random characteristics for the replacement of injuries in oral cavity without attending to the histological differences of each anatomical area. In the present work, we have revised previously published data regarding the main histological features of oral mucosa from different anatomical areas of the oral cavity in order to develop in the future a histological-tailored artificial oral mucosa. In other words, the future artificial substitute will keep the same histological characteristics that the injured area of the oral cavity which has to be repaired.

\section{HISTOLOGY OF NATIVE HUMAN ORAL MUCOSA}

\section{EPITHELIAL TISSUE}

The epithelial tissue offers a structural barrier that protects against the mechanical forces, the entry of external substances or microorganisms and the lost of fluids (2). The main cells of epithelium are the keratinocytes ( $90 \%$ of the total epithelial cell) while the rest is divided between permanent cells as melanocytes, Langerman and Merkel cells (9\%) and transitory cells as granulocytes, limphocytes and monocytes (1\%). Keratinocytes are responsable for creating all epithelial strata (basal and suprabasal layers), migrating from the deepest stratum to the most superficial and getting keratinizated in this migration process $(4,5)$. Basal layer is formed by keratinocytes with round nucleus that are in continuous division to ensure self-renovation of the epithelial tissue. Adjacent to this layer, spinous layer is composed by different layers of poligonal keratinocytes that are linked due to the presence of desmosomes-associated proteins and tonofilaments. Subsequently, granular layer is formed by squamous cells with small nucleus where keratohyaline granules and Odland's bodies are found. The most superficial layer is mainly composed by anucleate cells with wide expression of involucrin and filaggrin as key markers of maturation. In this context, attending to the grade of keratinocytes maduration and the anatomical location, three types of stratified epithelium can be observed in the oral cavity: i) orthokeratinizated where nuclei in the most superficial layer are absent, ii) parakeratinized where nuclei in the most superficial layer are pyknotic and iii) nonkeratinizated epithelia where there is not this superficial layer (4,5,11-15).

\section{BASEMENT MEMBRANE}

Epithelial and connective tissue have a permanent crosstalk due to the presence of the basement membrane. The main function of the basement membrane is to serve as a barrier for the pass of negative charges and act as guide of celular migration in the process of wound reepithelization $(4,5)$. Basement membrane is composed by a basal lamina and reticular lamina. The basal lamina is synthesized by epithelial cells mainly composed of integrins, laminin 5, entactin, heparin sulfate, collagen IV, fibronectin among other proteins. The reticular lamina is synthesized by connective cells with the presence of glucosaminoglycan matrix and two types of fibers: i) anchor fibers of collagen VII and $\mathrm{ii)}$ reticular fibers as reticulin (trimeric collagen III) (15-17).

\section{CONNECTIVE TISSUE AND SUBMUCOSA}

The connective tissue of the native human oral mucosa can be lax, dense or semidense according to the anatomical location into the oral cavity. The key function of the connective tissue is to serve as nutritional support to the epithelium. The connective tissue cell population are mainly composed by fibroblasts, macrophages, lymphocytes, mast cells and plasmatic cells $(4,5)$. Fibroblasts produce the fibrillar and non-fibrillar extracellular matrix as collagen I and VI, elastic fibers (elastin), reticular fibers (reticulin), proteoglycans (hyaluronic acid, heparin sulphate, syndecan, decorin) and glycoproteins (fibronectin, tenascin). Two zones are clearly defined in the connective tissue, the papillary layer and reticular layer. The papillary layer have a closed relation with epithelial rete ridges increasing the junction of both tissues and facilitating the exchange between epithelium and blood vessels. Apart from papillary layer, the reticular layer is located subjacent to the papillary layer and is rich in fibrilar components of the extracellular matrix $(5,12,15,17,8)$. Finally, connective tissue is linked to submucosa which is composed by lax connective tissue linked to subjacent tissues. The submucosa can be well-developed in areas exposed to masticatory forces or directly scarce in areas where there is rare movement. In addition, salivary glands, blood vessels, nerves and adipose tissue can be found in the submucosa $(5,12,13,16,18)$. 
ANATOMICAL CLASSIFICATION OF NATIVE HUMAN ORAL MUCOSA

Attending to the anatomical location in the oral cavity, the native human oral mucosa is classified in three types of oral mucosa with particular histological and functional characteristics $(5,16,19)$ (Table 1$)$ :

1. Masticatory mucosa: plays an important role in supporting due to the intense friction and pression forces of the masticatory movement. This mucosa is found in gingiva and hard palade. Histological features include orthokeratinized or parakeratinized epithelium with great amount of rete ridges. In addition, the connective tissue may vary from semidense to dense. In the particular case of the gingiva, there is a scarce submucosa that differs from the lateral surface of hard palate where the submucosa present glandular and adipose tissue.

2. Lining mucosa: the main function is the protection of the oral cavity inside acting as a barrier for microorganisms and other substances. Furthermore, elastic fibers are abundant allowing the streching and relaxing of the tissue. This mucosa is found in lips, soft palade, cheeks, ventral tongue surface and mouth's floor. Epithelium is nonkeratinizated, connective tissue is lax or semidense and submucosa is well defined with salivary glands, adipose tissue and striated muscle fibers.

\begin{tabular}{|c|c|c|c|c|c|}
\hline & Localization & Histology & Function & Immunohistochemistry & Bibliography \\
\hline \multirow[b]{2}{*}{$\begin{array}{l}\text { Masticatory } \\
\text { mucosa }\end{array}$} & Gingiva & $\begin{array}{l}\text { Thick } \\
\text { parakeratinized } \\
\text { epithelium, lax } \\
\text { or semidense } \\
\text { connective tissue } \\
\text { with papillae and } \\
\text { without submucosa }\end{array}$ & \multirow[b]{2}{*}{$\begin{array}{l}\text { Support } \\
\text { masticatory } \\
\text { forces }\end{array}$} & $\begin{array}{l}\text { CKs } 1,2,4,5,6,8,10 \\
11,13,14,16,18,19\end{array}$ & \\
\hline & Hard palate & $\begin{array}{l}\text { Thick } \\
\text { orthokeratinized } \\
\text { epithelium with } \\
\text { dense connective } \\
\text { tissue and without } \\
\text { submucosa or } \\
\text { with lax papillary } \\
\text { connective tissue } \\
\text { and well defined } \\
\text { submucosa. }\end{array}$ & & CKs $1,6,10,16,76$ & $\begin{array}{l}(5,10,16 \\
19,22,23 \\
25,26)\end{array}$ \\
\hline \multirow{4}{*}{$\begin{array}{l}\text { Lining } \\
\text { mucosa }\end{array}$} & $\begin{array}{l}\text { Mouth's } \\
\text { floor* }\end{array}$ & \multirow{4}{*}{$\begin{array}{l}\text { Lax and elastic } \\
\text { connective tissue } \\
\text { with submucosa } \\
\text { linked to muscle } \\
\text { Lax connective } \\
\text { tissue without } \\
\text { submucosa }\end{array}$} & \multirow{4}{*}{$\begin{array}{l}\text { Protection } \\
\text { allowing } \\
\text { the tissue } \\
\text { streching } \\
\text { and relaxing }\end{array}$} & $\begin{array}{l}\text { CKs 4, 5, 6, 13, 14, 16, } \\
19\end{array}$ & \multirow{4}{*}{$\begin{array}{l}(5,10,12 \\
16,19,24)\end{array}$} \\
\hline & $\begin{array}{l}\text { Lips and } \\
\text { cheeks* }\end{array}$ & & & CKs $1,4,5,13,14$ & \\
\hline & $\begin{array}{l}\text { Ventral } \\
\text { tongue* }\end{array}$ & & & CKs $4,5,6,13,14,16$ & \\
\hline & Soft palate* & & & CKs $7,8,18,19$ & \\
\hline \multirow{3}{*}{$\begin{array}{l}\text { Specialized } \\
\text { mucosa }\end{array}$} & $\begin{array}{l}\text { Dorsal } \\
\text { tongue** }\end{array}$ & \multirow{3}{*}{$\begin{array}{l}\text { Connective tissue } \\
\text { and submucosa } \\
\text { fusionated and } \\
\text { linked to the muscle }\end{array}$} & & $\begin{array}{l}\text { CKs } 1,2,4,5,6,13,14 \\
15,16,17\end{array}$ & \multirow{3}{*}{$\begin{array}{l}(5,16,19, \\
27,28)\end{array}$} \\
\hline & $\begin{array}{l}\text { Taste } \\
\text { papillae** }\end{array}$ & & taste stımulı & $\begin{array}{l}\text { CKs } 1,2,4,10,11,13 \\
16 * * *\end{array}$ & \\
\hline & $\begin{array}{l}\text { Lingual } \\
\text { tonsil* }\end{array}$ & & Defensive & CKs $5,6,7,13,14$ & \\
\hline
\end{tabular}

Table 1. Histological characterization of native human oral mucosa. Anatomical localization, histology, function and immmunohistochemistry of epithelium. *: nonkeratinized epithelium. **: parakeratinized epithelium. ***: in taste buds, CKs 8, 18, 19 are expressed. 
3. Specialized mucosa: in the case of mucosa with taste function, specially in dorsal tongue and taste papillae, a parakeratinizated epithelium is found. For mucosa with defensive function, specially in lingual tonsil, a non-keratinizated epithelium can be identify. Both types of specialized mucosas present connective tissue and submucosa.

\section{CURRENT HISTOLOGY FINDINGS IN NATIVE} HUMAN ORAL MUCOSA

Several works have used different histological techniques to identify tissue structure, cellular components and the extracellular matrix of native human oral mucosa. Most of the publications use rutinary hematoxylin and eosine for the visualization of acidophil and basophilic components (20). In addition, histological features for native human oral mucosas are also investigated by using immunohistology and histochemical techniques. In the present review, we pretend to highlight the most relevant findings of current histological studies regarding the epithelium, basal membrane, connective tissue and submucosa of the native human oral mucosa

\section{EPITHELIAL TISSUE}

For histological study of the epithelium of the native human oral mucosa the most used histological technique is the immunohistochemistry to detect key epithelium-related proteins, cytokeratins (CKs). In this milieu, CKs are a cytoskeletal protein family of intermediated size synthesized by epithelial cells classically divided in type I or acidic proteins (CK 9, 10, 11, 12, 13, 14, 15, 16, 17, 18, 19, 20 and others) and type II or basic proteins (CK 1, 2, 3, 4, $5,6,7,8)(21)$. Most of the scientific publications associate the expression of CKs 5-14 and 17 to the basal layer cells. The CKs 4-13, and 6-16 expression to the suprabasal layers and CKs 3-12 and 10 are linked to the most superficial epithelial layers of the keratinized oral mucosa (10,22-24) (Table 2). Different authors classify some CKs as specific of keratinized or nonkeratinized epithelia. However, this affirmation is not correct at all because of these CKs also can be found in the opposed epithelia. For example, Winning et al classified CKs 6-16 as specific proteins of keratinized epithelia but they are also found in nonkeratinized epithelium as mouth's floor and ventral tongue $(10,15,24)$.

Several authors have used CKs as epithelial markers in the different types of oral mucosa (masticatory, lining, and specialized mucosa) (Table 1). First, for masticatory mucosa as gingiva showed possitive expression of CKs $1,2,4,5,6,8,10,11,13,14,16,17$, 18 and $19(10,25)$. In the case of masticatory mucosa as hard palate CKs 1, 6, 10, 16 and 76 were possitively expressed $(10,22,23,26)$.
Secondly, in the case of lining mucosa as mouth's floor and ventral tongue CKs 4, 5, 6, 13, 14, 16 were found. However, CK 19 expression was exclusively found in mouth's floor (24). In contrast, lips and soft palate were substatially different. In the case of lips CKs 1, 4, $5,13,14$ were expressed (12) and for soft palate CKs 7, 8,18 and 19 were also positive (10). Furthermore, for lining mucosa as cheeks an epithelia pattern based on CKs expression was not found.

Finally, in areas with specialized mucosa as dorsal tongue and lingual tonsil a common CKs expression was found (CKs 5, 6, 13, 14) being CKs 1, 2, 4, 15, 16 and 17 exclusive for dorsal tongue. In the same way, CK 7 was unique for lingual tonsil $(27,28)$. Different types of taste papillae are located along the tongue expressing on the top CKs 1, 2, 4, 10, 11, 13, 16. Strinkingly, taste buds situated on the side of papillae show a high expression of CKs 8, 18, 19 similar to simple epithelium (28).

Another proteins involve in oral mucosa epithelial differentiation are filaggrin, involucrin and loricrin. According to this, filaggrin and involucrin were expressed in masticatory and specialized keratinized oral mucosa. Nonetheless, in non-keratinized epithelium as lining mucosa and lingual tonsil of specialized oral mucosa, filaggrin and involucrin proteins were absent $(22,24)$ (Table 2$)$.

Apart from the use of CKs as key epithelial markers, few authors have also used immunohistochemical techniques to detect another epithelial markers, usefull for the characterization of oral mucosa epithelium including CD44 (a cell-cell adhesion marker), desmoglein, desmoplakin, desmokollin (desmosomes associated proteins), connexin-26 and 43 and $\alpha 4-\beta 6$ integrins (junction of epithelial and connective tissue) that were expressed in all types of oral mucosa $(5,12,15)$ (Table 2).

\section{BASEMENT MEMBRANE}

Histological characterization of basement membrane is based on immunohistochemical and histochemical techniques due to the amount of proteins of different nature. As we mentioned before, basement membrane is composed by basal lamina and reticular lamina. In this regard, few studies have reported the presence of $\mathrm{BP}$ 180, BP 230, ladinin, laminin-5, entactin, fibronectin and collagen IV as markers of basal lamina. In terms of reticular lamina, the literature have addressed the expression of collagen III and VII $(15,29)$ (Table 3$)$. All these markers play an important role in native human oral mucosa differentiation and characterization. Furthermore, histochemical techniques have detected glycoproteins of basement membrane using periodic acid-Schiff staining $(11,30)$. Moreover, for the reticular lamina characterization, Gomori's technique has been used to detect reticulin fibers formed by trimeric collagen type III $(19,30)$ (Table 4$)$. 


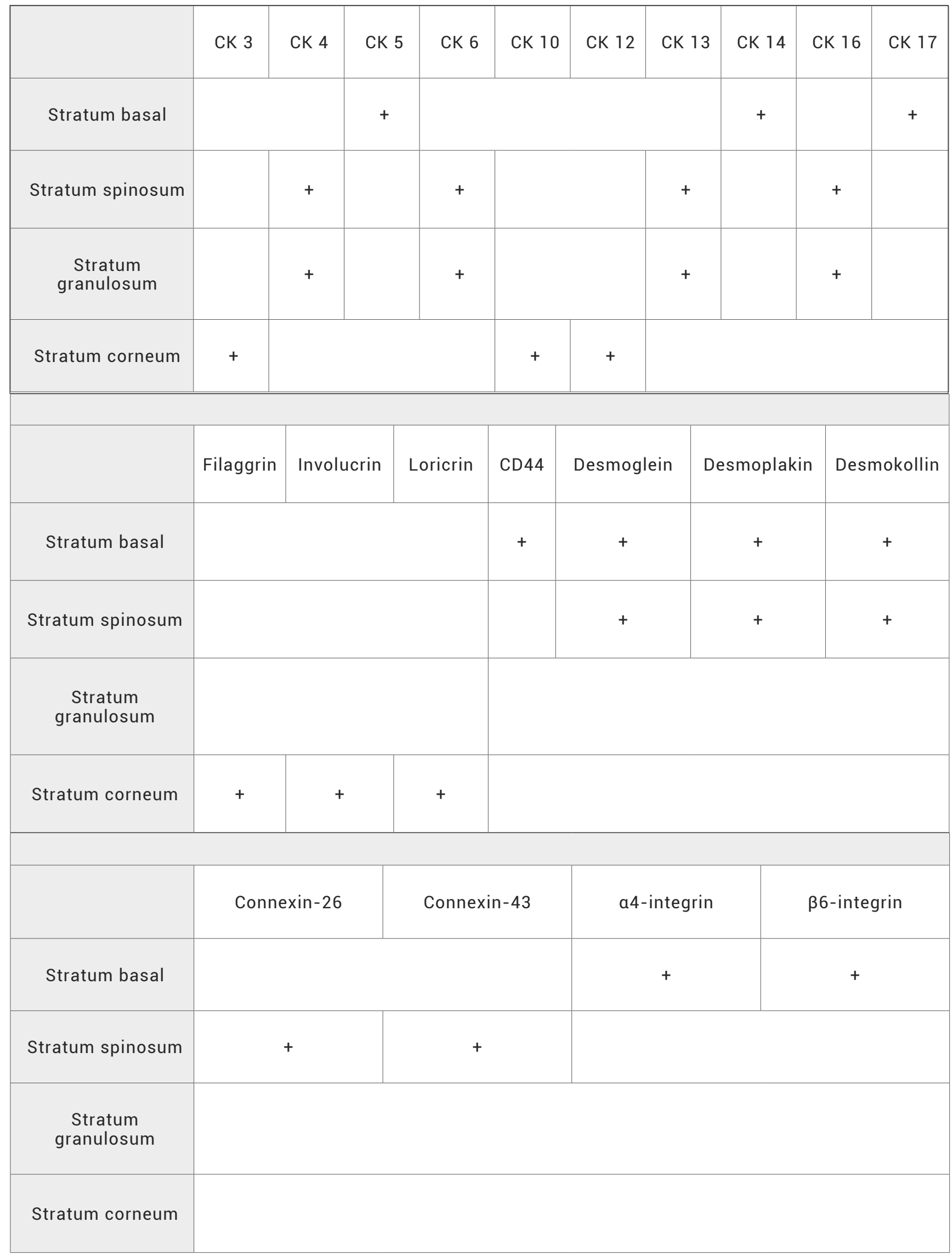

Table 2. Characterization of epithelial markers in native human oral mucosa.

+: reported by the literature. 


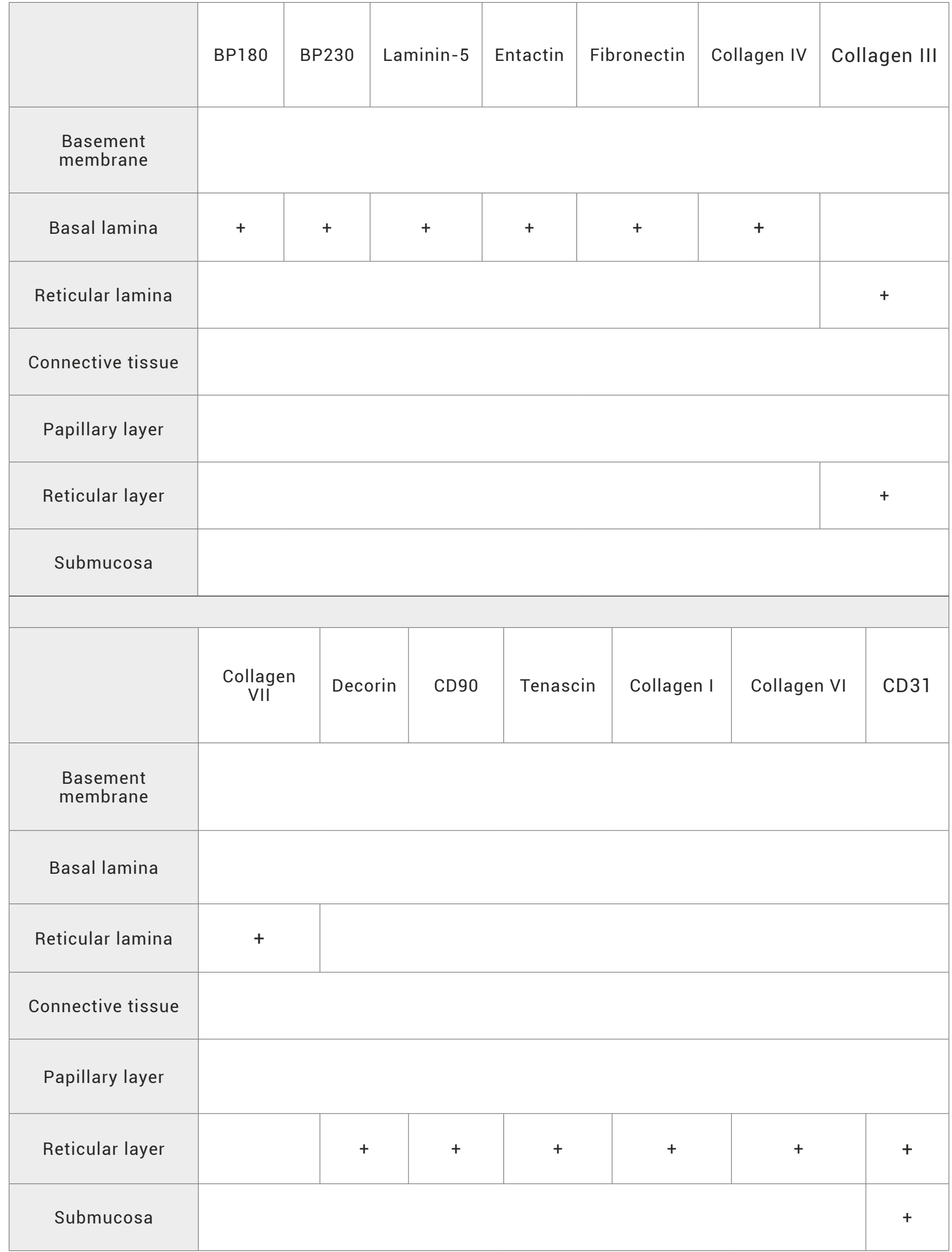

Table 3. Characterization of the basement membrane, the connective tissue and the submucosa. +: reported by the literature. + : reported by the literature. 


\begin{tabular}{|c|c|c|c|c|c|c|c|c|}
\hline & Mas & Pic & PAS & $A B$ & Gom & Ver & ORO & Bibliography \\
\hline \multicolumn{9}{|l|}{$\begin{array}{l}\text { Basement } \\
\text { membrane }\end{array}$} \\
\hline $\begin{array}{l}\text { Basal } \\
\text { lamina }\end{array}$ & & & + & & & & & $(5,11,30)$ \\
\hline $\begin{array}{l}\text { Reticular } \\
\text { lamina }\end{array}$ & & & & & + & & & $(19,30)$ \\
\hline \multicolumn{9}{|l|}{$\begin{array}{l}\text { Connective } \\
\text { tissue }\end{array}$} \\
\hline $\begin{array}{l}\text { Papillary } \\
\text { layer }\end{array}$ & & & + & + & & + & & $\begin{array}{c}(5,11,19,20,30 \\
32)\end{array}$ \\
\hline $\begin{array}{l}\text { Reticular } \\
\text { layer }\end{array}$ & + & + & + & + & + & + & & $\begin{array}{c}(5,11,19,20,30 \\
32)\end{array}$ \\
\hline Submucosa & & & + & + & & & + & $(5,12,33)$ \\
\hline
\end{tabular}

Table 4. Histochemical characterization of the basement membrane, the connective tissue and the submucosa. +: possitive staining. Mas: Masson staining for collagen I. Pic: picrosirius staining for collagen I. PAS: periodic acid-Schiff staining for glycoproteins as integrins, laminins, entactin, fibronectin and tenascin. AB: alcian blue staining for proteoglycans as hialuronic acid, heparin sulphate, syndecan and decorin. Gom: Gomori's technique for reticulin formed by trimeric collagen III. Ver: Verhoeff staining for elastic fibers formed by elastin and fibrilin. ORO: Oil Red O staining for neutral lipids.

\section{CONNECTIVE TISSUE AND SUBMUCOSA}

Connective tissue is rich in fibrillar and non fibrillar components. The main fibrillar component is the collagen type I, III and VI that has been widely used for connective tisssue characterization by immunohistochemistry techniques. Likewise, the non fibrillar components such as decorin and tenascin have been also identified by immunohistochemistry. CD90 positive expression has been linked to the mesenchymal origin of fibroblasts, the main cellular component of the connective and submucosa tissue $(15,29,31)$ (Table 3).

The use of histochemistry tecniques in native human oral mucosa characterization have included trichrome of Masson and picrosirius stainings for the detection of collagen I. In addition, periodic acidSchiff staining confirms the presence of glycoproteins as tenascin and fibronectin. For the detection of proteoglycans, alcian blue staining was used accompained by the detection of other proteoglycans such as syndecan and decorin. Trimeric collagen III fiber called reticulin is visualizated by the use of Gomori's technique. Finally, elastic fibers formed by elastin and fibrilin are confirmed by the Verhoeff staining $(5,11,19,20,30,32)$ (Table 4$)$.
Additionally, connective and submucosa tissues are immunohistochemically recognized by the use of endothelial markers as CD31 due to the presence of blood vessels and capillaries $(5,12,29)$ (Table 3 ) and histochemically identified by the use of Oil Red $\mathrm{O}$ staining which colours the adipose tissue found in some types of submucosa $(5,12,33)$ (Table 4$)$.

HISTOLOGICAL STUDIES OF ARTIFICIAL ORAL MUCOSA DEVELOPED BY TISSUE ENGINEERING

Several research groups have developed different types of artificial oral mucosa (Table 5) using several epithelial, basement membrane, connective and submucosa tissue markers. However, in some cases morphological classification of artificial oral mucosa substitutes are rare mentionated or remain unclear. According to this, the analysis of the cytokeratin expression profile will be a helpful tool to classify the type of oral mucosa substitute and to match the proper substitute to recipient zone developing a tailored artificial oral mucosa substitutes.

In this regard, immunohistochemical methods for the classification of oral mucosa should include 
proliferative basal cells markers as CKs 5 and 14 stratification and maduration of epithelial layer using CKs 4 and 13 markers, keratinization using markers as CKs 3, 10 and 12. According to the findings of the literature, to include a extended pool of cytokeratins will be helpful to classify the type artificial oral mucosa developed by tissue engineering (10,15,2224).

Three groups, Garzón et al, Nishiyama et al and Almela et al, have used antibodies for the detection of cytokeratins associated with proliferative basal cells, stratification and keratinization (34-37). In contrast, numerous research groups have only describe CKs expression for one or two markers of proliferative basal cells, stratification or keratinization (38-48). However, Iida et al have not used any epithelial markers to characterize oral mucosa epithelium (49).

Furthermore, most of the artificial oral mucosa developed by tissue engineering have shown stratification and maduration of the epithelial tissue according to the positive expression of CK 4 and 13, both, present in suprabasal layers of epithelia $(34-42,44,45,47,48)$. According to the cytokeratin expression profile, oral mucosa substitutes produced by Qi et al, Izumi et al, Bayar et al, Lauer et al and Almela et al could be classified as keratinized mucosa $(34,39,44,46)$. Moreover, substitutes developed by Garzón et al and SánchezQuevedo et al are classified as non-keratinized mucosa $(35,36,47)$. Nishiyama et al produced both types in their study (37).

According to the review of the literature, the scarce amount of cytokeratins used to characterize epithelium in artificial oral mucosa developed by tissue engineering may limit the possibility to classify the specific type of oral mucosa with the anatomical site. Nevertheless, there are few groups that produced artificial oral mucosa which can be classified as specific of an oral cavity area. Oral mucosa of Lauer et al, Garzón et al and Alaminos et al could be specific for gingiva but the lack of expression of CK 10 in artificial oral mucosa developed by Garzón et al and Alaminos et al should mimick in a better way the expression profile of the mouth's floor.

In addition, the oral mucosa of Garzón et al could be used for soft palate repair while the oral mucosa of Alaminos et al could be used for lips and dorsal tongue repair $(35,36,38,44)$. Surprinsingly, oral mucosa substitutes developed by Garzón and collaborators did not show keratinized cytokeratins expression in vitro but when the engineered tissue was implanted in athymic mice the expression pattern changed starting to express CK $10(35,36)$. This finding point out the importance of in vitro and in vivo characterization of artificial oral mucosa.

\section{FUTURE PERSPECTIVES}

One of the main challenges in the field of bioengineered oral mucosa is to reproduce in vitro an artificial oral mucosa with the same epithelial characteristics of the specific injured anatomical area (34-49). To achive this, future studies should be focused in the histological characterization of the different anatomical areas of native oral mucosa in order to stablish the minimal criteria to develop artificial oral mucosa of specific anatomical areas. The last challenge in oral mucosa tissue engineering will be to produce vascularized artificial oral mucosa to ensure that post-implanted tissue will be linked to the human capillaries by anastomosis enhancing the graft survival of bioengineered tissue (50).

\section{CONCLUSION}

The knowledge of the main anatomical and histological features of the native human oral mucosa is essential for the fabrication of human oral mucosa substitutes. In this sence, the development of tailored-oral mucosa substitutes should require the deep characterization of cytokeratins expression profile in order to achive the main characteristics of each type of oral mucosa in the oral cavity. In addition, the evidence that in vivo enviroment tend to modified the cytokeratin expression pattern is enough reason to reccomend in vivo testing of newly-produce oral mucosa substitutes.

\section{BIBLIOGRAPHIC REFERENCES}

1. Souza LR, Oliveira MM, Basile JR, Souza LN, Souza ACR, Haikal DS, et al. Anatomical and Physiopathological Aspects of Oral Cavity and Oropharynx Components Related to Oropharyngeal Dysphagia. IntechOpen: Rijeka; 2015. DOI: $10.5772 / 60766$

2. Kinikoglu B, Damour O, Hasirci V. Tissue engineering of oral mucosa: a shared concept with skin. J Artif Organs. 2015;18(1):8-19. DOI: 10.1007/s10047-014-0798-5

3. Mackenzie IC, Binnie WH. Recent advances in oral mucosal research. J Oral Pathol. 1983;12(6):389-415. DOI: 10.1111/ j.1600-0714.1983.tb00353.x

4. Garzón I. Estudio de marcadores de diferenciación epitelial en mucosa oral construida por ingeniería tisular: Universidad de Granada; 2009.

5. Gómez ME, Campos A. Histología y embriología bucodental: bases estructurales de la patología, el diagnóstico, la terapeutica y la prevención odontológica. Panamericana: Madrid; 2002 


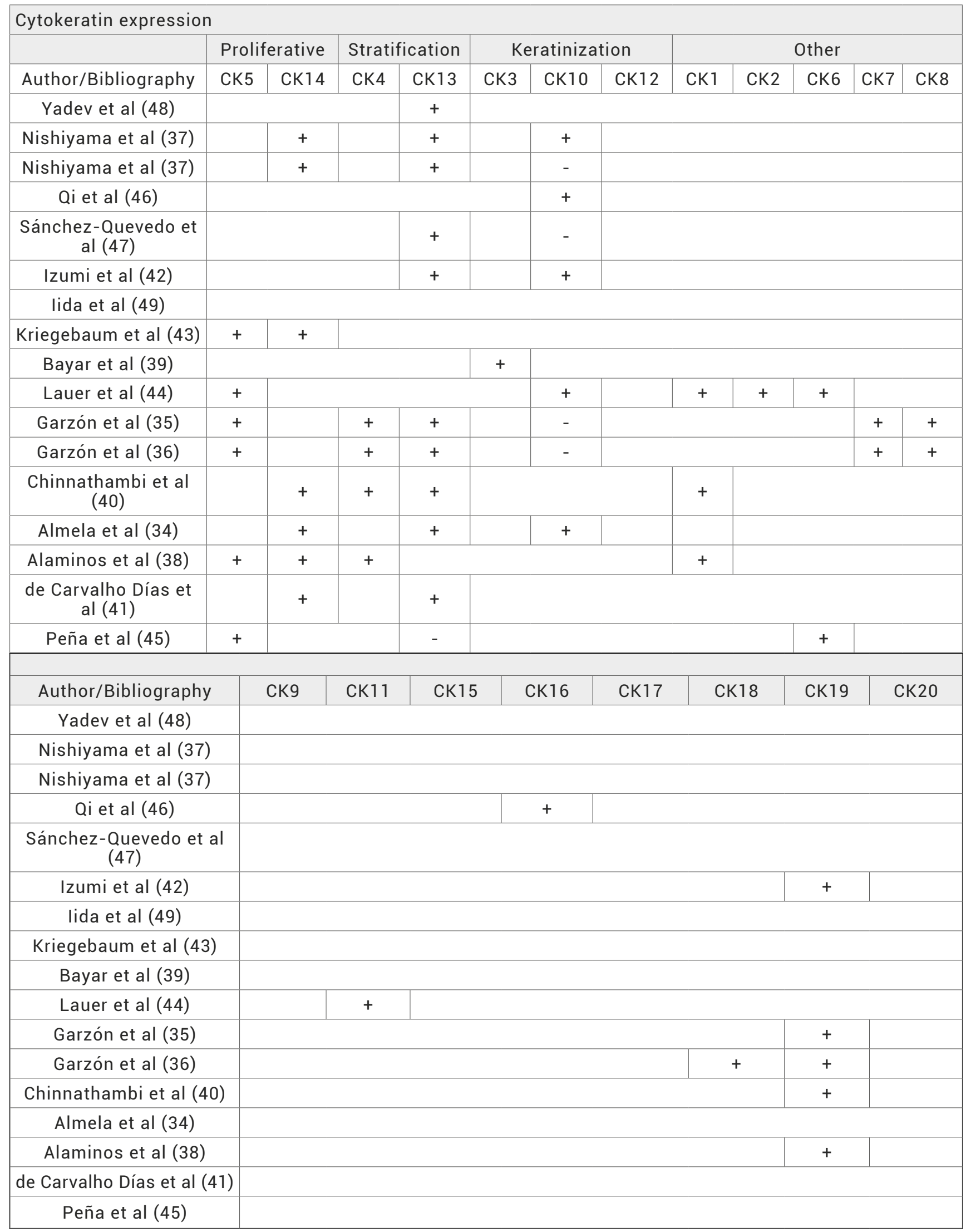

Table 5. Cytokeratins expression pattern of artificial oral mucosas reported by the literature. +: possitive CK reaction. -: negative CK reaction. White: cytokeratin expression not studied. Proliferative: proliferative basal cells cytokeratins (CKs 5 and 14). Stratification: stratification associated cytokeratins (CKs 4 and 13). Keratinization: keratinization associated cytokerains (CKs 3, 10 and 12). Other: other cytokeratins (CKs 1, 2, 6, 7, 8, 9, 11, 15, 16, 17, 18, 19, 20) 
6. Mueller DT, Callanan VP. Congenital malformations of the oral cavity. Otolaryngol Clin North Am. 2007;40(1):141-60, vii. DOI: 10.1016/j.otc.2006.10.007

7. Koray M, Tosun T. Oral mucosal trauma and injuries. IntechOpen: Rijeka; 2019. DOI: 10.5772/intechopen.81201

8. Golinski P, Gröger S, Meyle J. Bioengineering and Analysis of Oral Mucosa Models. In: Kamolz LP., Lumenta D. (eds) Dermal Replacements in General, Burn, and Plastic Surgery. Springer, Vienna. 2013:173-92. DOI: 10.1007/978-3-70911586-2_15

9. Llames S, Recuero I, Romance A, Garcia E, Pena I, Del Valle $A F$, et al. Tissue-engineered oral mucosa for mucosal reconstruction in a pediatric patient with hemifacial microsomia and ankyloglossia. Cleft Palate Craniofac J. 2014;51(2):246-51. DOI: 10.1597/12-245

10. Rao RS, Patil S, Ganavi BS. Oral cytokeratins in health and disease. J Contemp Dent Pract. 2014;15(1):127-36. DOI: 10.5005/jp-journals-10024-1502

11. Adams D. Keratinization of the oral epithelium. Ann R Coll Surg Engl. 1976;58(5):351-8.

12. Berkovitz BKB, Holland GR, Moxham BJ. Oral Anatomy, Histology and Embryology. Mosby Elsevier: Kidlington; 2009.

13. Bergmeier LA. Oral Mucosa in Health and Disease. Springer: Cham; 2018.

14. Groeger S, Meyle J. Oral Mucosal Epithelial Cells. Front Immunol. 2019;10:208. DOI: 10.3389/fimmu.2019.00208

15. Winning TA, Townsend GC. Oral mucosal embryology and histology. Clin Dermatol. 2000;18(5):499-511. DOI: 10.1016/ s0738-081x(00)00140-1

16. Chandra S. CS, Chandra M., Chandra G. and Chandra N Textbook of Dental and Oral Histology with Embryology and Multiple Choice Questions. Jaypee; 2010.

17. Groeger SE, Meyle J. Epithelial barrier and oral bacterial infection. Periodontol 2000. 2015;69(1):46-67. DOI: 10.1111/ prd.12094

18. Moharamzadeh K, Colley H, Murdoch C, Hearnden V, Chai WL, Brook IM, et al. Tissue-engineered oral mucosa. J Dent Res. 2012;91(7):642-50. DOI: 10.1177/0022034511435702

19. Ciano J, Beatty BL. Regional quantitative histological variations in human oral mucosa. Anat Rec (Hoboken). 2015;298(3):562-78. DOI: 10.1002/ar.23097

20. Vela-Romera A, Carriel V, Martin-Piedra MA, Aneiros-Fernandez J, Campos F, Chato-Astrain J, et al. Characterization of the human ridged and non-ridged skin: a comprehensive histological, histochemical and immunohistochemical analysis. Histochem Cell Biol. 2019;151(1):5773. DOI: $10.1007 / \mathrm{s} 00418-018-1701-x$
21. Moll R, Franke WW, Schiller DL, Geiger B, Krepler R. The catalog of human cytokeratins: patterns of expression in normal epithelia, tumors and cultured cells. Cell. 1982;31(1):11-24. DOI: 10.1016/0092-8674(82)90400-7

22. Dale BA, Salonen J, Jones AH. New approaches and concepts in the study of differentiation of oral epithelia. Crit Rev Oral Biol Med. 1990;1(3):167-90. DOI: 10.1177/10454411900010030201

23. Guo JH, Maltha JC, He SG, Krapels IP, Spauwen PH, Steegers-Theunissen RP, et al. Cytokeratin expression in palatal and marginal mucosa of cleft palate patients. Arch Oral Biol. 2006;51(7):573-80. DOI: 10.1016/j.archoralbio.2006.01.004

24. van der Velden L-A, Schaafsma H, Manni J, Ramaekers F, Kuijpers W. Expression of Cytokeratin Subtypes and Vimentin in Squamous Cell Carcinoma of the Floor of the Mouth and the Mobile Tongue. Oto rhino laryngol nova. 2001;11:186-92. DOI: 10.1159/000063015

25. Ouhayoun JP, Gosselin F, Forest N, Winter S, Franke WW. Cytokeratin patterns of human oral epithelia: differences in cytokeratin synthesis in gingival epithelium and the adjacent alveolar mucosa. Differentiation. 1985;30(2):123-9. DOI: 10.1111/j.1432-0436.1985.tb00523.x

26. Gibbs S, Ponec M. Intrinsic regulation of differentiation markers in human epidermis, hard palate and buccal mucosa. Arch Oral Biol. 2000;45(2):149-58. DOI: 10.1016/s00039969(99)00116-8

27. Clark MA, Wilson C, Sama A, Wilson JA, Hirst BH. Differential cytokeratin and glycoconjugate expression by the surface and crypt epithelia of human palatine tonsils. Histochem Cell Biol. 2000;114(4):311-21. DOI: 10.1007/s004180000198

28. Sawaf MH, Ouhayoun JP, Shabana AH, Forest N. Cytokeratin expression in human tongue epithelium. Am J Anat. 1990;189(2):155-66. DOI:10.1002/aja.1001890206

29. Heller M, Frerick-Ochs EV, Bauer HK, Schiegnitz E, Flesch $\mathrm{D}$, Brieger J, et al. Tissue engineered pre-vascularized buccal mucosa equivalents utilizing a primary triculture of epithelial cells, endothelial cells and fibroblasts. Biomaterials. 2016;77:207-15. DOI: 10.1016/j.biomaterials.2015.10.073

30. Oliveira AC, Garzon I, Ionescu AM, Carriel V, Cardona Jde L, Gonzalez-Andrades $\mathrm{M}$, et al. Evaluation of small intestine grafts decellularization methods for corneal tissue engineering. PLoS One. 2013;8(6):e66538. DOI: 10.1371/journal.pone.0066538

31. Montano I, Schiestl C, Schneider J, Pontiggia L, Luginbuhl $\mathrm{J}$, Biedermann T, et al. Formation of human capillaries in vitro: the engineering of prevascularized matrices. Tissue Eng Part A. 2010;16(1):269-82. DOI: 10.1089/ten.TEA.2008.0550

32. Carriel VS, Aneiros-Fernandez J, Arias-Santiago S, Garzon IJ, Alaminos M, Campos A. A novel histochemical method for a simultaneous staining of melanin and collagen fibers. J Histochem Cytochem. 2011;59(3):270-7. DOI: $10.1369 / 0022155410398001$ 
33. Wang $Y$, Goulart RA, Pantanowitz L. Oil red $O$ staining in cytopathology. Diagn Cytopathol. 2011;39(4):272-3. DOI: $10.1002 /$ dc. 21390

34. Almela T, Al-Sahaf $\mathrm{S}$, Bolt R, Brook IM, Moharamzadeh K. Characterization of Multilayered Tissue-Engineered Human Alveolar Bone and Gingival Mucosa. Tissue Eng Part C Methods. 2018;24(2):99-107. DOI: 10.1089/ten.TEC.2017.0370

35. Garzon I, Sanchez-Quevedo MC, Moreu G, Gonzalez-Jaranay $M$, Gonzalez-Andrades $M$, Montalvo $A$, et al. In vitro and in vivo cytokeratin patterns of expression in bioengineered human periodontal mucosa. J Periodontal Res. 2009;44(5):588-97. DOI: 10.1111/j.16000765.2008.01159.x

36. Garzon I, Serrato D, Roda O, Del Carmen Sanchez-Quevedo M, Gonzales-Jaranay M, Moreu G, et al. In vitro cytokeratin expression profiling of human oral mucosa substitutes developed by tissue engineering. Int J Artif Organs. 2009;32(10):711-9. DOI: 10.1177/039139880903201002

37. Nishiyama K, Akagi T, Iwai S, Akashi M. Construction of Vascularized Oral Mucosa Equivalents Using a Layer-by-Layer Cell Coating Technology. Tissue Eng Part C Methods. 2019;25(5):262-75. DOI: 10.1089/ten.TEC.2018.0337

38. Alaminos M, Garzon I, Sanchez-Quevedo MC, Moreu G, Gonzalez-Andrades M, Fernandez-Montoya A, et al. Time-course study of histological and genetic patterns of differentiation in human engineered oral mucosa. J Tissue Eng Regen Med. 2007;1(5):350-9. DOI: 10.1002/term.38

39. Bayar GR, Aydintug YS, Gunhan O, Ozturk K, Gulses A. Ex vivo produced oral mucosa equivalent by using the direct explant cell culture technique. Balkan Med J. 2012;29(3):295-300. DOI: 10.5152/balkanmedj.2012.011

40. Chinnathambi S, Tomanek-Chalkley A, Ludwig N, King E, DeWaard R, Johnson G, et al. Recapitulation of oral mucosal tissues in long-term organotypic culture. Anat Rec A Discov Mol Cell Evol Biol. 2003;270(2):162-74. DOI: 10.1002/ar.a.10021

41. de Carvalho Dias K, de Sousa DL, Barbugli PA, Cerri PS, Salih VM, Vergani CE. Development and characterization of a 3D oral mucosa model as a tool for host-pathogen interactions. J Microbiol Methods. 2018;152:52-60. DOI: 10.1016/j.mimet.2018.07.004

42. Izumi K, Terashi H, Marcelo CL, Feinberg SE. Development and characterization of a tissue-engineered human oral mucosa equivalent produced in a serum-free culture system. J Dent Res. 2000;79(3):798-805. DOl: $10.1177 / 00220345000790030301$

43. Kriegebaum $U$, Mildenberger M, Mueller-Richter UD, Klammert U, Kuebler AC, Reuther T. Tissue engineering of human oral mucosa on different scaffolds: in vitro experiments as a basis for clinical applications. Oral Surg Oral Med Oral Pathol Oral Radiol. 2012;114(5 Suppl):S190-8. DOI: 10.1016/j. oooo.2011.10.019
44. Lauer G, Schimming R. Tissue-engineered mucosa graft for reconstruction of the intraoral lining after freeing of the tongue: a clinical and immunohistologic study. J Oral Maxillofac Surg. 2001;59(2):169-75; discussion 75-7. DOI: 10.1053/joms.2001.20489

45. Pena I, Junquera LM, Meana A, Garcia E, Garcia V, De Vicente JC. In vitro engineering of complete autologous oral mucosa equivalents: characterization of a novel scaffold. J Periodontal Res. 2010;45(3):375-80. DOI: 10.1111/j.16000765.2009.01248.x

46. Qi F, Yoshida $T$, Koike $T$, Aizawa $H$, Shimane $T$, Li $Y$, et al. Construction and characterization of human oral mucosa equivalent using hyper-dry amniotic membrane as a matrix. Arch Oral Biol. 2016;65:26-34. DOI: 10.1016/j.archoralbio.2016.01.011

47. Sanchez-Quevedo MC, Alaminos M, Capitan LM, Moreu G, Garzon I, Crespo PV, et al. Histological and histochemical evaluation of human oral mucosa constructs developed by tissue engineering. Histol Histopathol. 2007;22(6):631-40. DOI: 10.14670/HH-22.631

48. Yadev NP, Murdoch C, Saville SP, Thornhill MH. Evaluation of tissue engineered models of the oral mucosa to investigate oral candidiasis. Microb Pathog. 2011;50(6):278-85. DOI: 10.1016/j.micpath.2010.11.009

49. Iida T, Takami Y, Yamaguchi R, Shimazaki S, Harii K. Development of a tissue-engineered human oral mucosa equivalent based on an acellular allogeneic dermal matrix: a preliminary report of clinical application to burn wounds. Scand J Plast Reconstr Surg Hand Surg. 2005;39(3):138-46. DOI: $10.1080 / 0284431051006376$

50. Wang K, Lin RZ, Melero-Martin JM. Bioengineering human vascular networks: trends and directions in endothelial and perivascular cell sources. Cell Mol Life Sci. 2019;76(3):42139. DOI: 10.1007/s00018-018-2939-0

\section{CONFLICT OF INTERESTS}

The authors of this article declare that they have no conflict of interest with respect to what is stated in this work.

\section{Si desea citar nuestro artículo:}

Ibáñez Cortés M, Garzón I. Study of the histological and anatomical characteristics of the human oral mucosa. A step towards the developement of tailored-artificial oral mucosa. Actual Med. 2021; 106(813): 177-187. DOI: 10.15568/ am.2021.813.rev01 